\title{
Rural land use transition of mountainous areas and policy implications for land consolidation in China
}

\author{
ZHANG Bailin" ${ }^{1}$ SUN Piling ${ }^{2}$, 'JIANG Guanghui ${ }^{3}$, ZHANG Ruijuan", \\ GAO Jiangbo ${ }^{4}$
}

1. School of Economics and Management, Tianjin Polytechnic University, Tianjin 300387, China;

2. School of Geography and Tourism, Qufu Normal University, Rizhao 276826, Shandong, China;

3. State Key Laboratory of Earth Surface Processes and Resource Ecology, School of Natural Resources, Faculty of Geographical Science, Beijing Normal University, Beijing 100875, China;

4. Key Laboratory of Land Surface Pattern and Simulation, Institute of Geographic Sciences and Natural Resources Research, CAS, Beijing 100101, China

\begin{abstract}
The cultivation of mountainous land results in water loss and soil erosion. With rapid urbanization and industrialization in China, labor emigration relieves the cultivation of mountainous areas in regions with high poverty and leads to a significant land use transition. This research built an analysis framework for "land use transition - driving mechanism - effects responses" for mountainous areas of China undergoing land use transition and then proposed the direction of mountainous land consolidation. The results showed that the turning point of land use morphology was the core of rural land use transition in mountainous areas. The expansion of cropland and the contraction of forestland have transitioned to the abandonment of cropland and the expansion of forestland; this transition was the main characteristic of the dominant land use change. Land marginalization and land ecological functional recovery were the main characteristics of the recessive land use transition in mountainous areas. Socioeconomic factors were the primary driving forces during land use transition in mountainous areas, with labor emigration being the most direct force. The rising costs of farming and the challenging living conditions causing labor emigration were fundamental driving forces. Rural land use transition in mountainous areas reduced the vulnerability of the ecological function of land ecosystems. The advantages and disadvantages of the socioeconomic effects should focus on rural development of mountainous areas as well as the livelihood of farmers; this should be further supported by empirical and quantitative research. Rural land use transition of mountainous areas improves natural restoration and is related to socioeconomic development. Rural land consolidation of mountainous areas should conform to land use transition, with the goal of shifting from the increase of cultivated land to the synergies of ecological and environmental protection.
\end{abstract}

Received: 2019-01-05 Accepted: 2019-03-12

Foundation: National Natural Science Foundation of China, No.41801193, No.41671519; Tianjin Science and Technology Development Strategic Research Plan Project, No.17ZLZXZF00170

Author: Zhang Bailin (1987-), Associate Professor, specialized in land use transition and rural development. E-mail: zhangbailin135@163.com

*Corresponding author: Jiang Guanghui, PhD, E-mail: macrophage@126.com 
Keywords: land use transition; driving force; effect; land consolidation; mountainous area

\section{Introduction}

In a traditional agricultural society, farming is the main source of livelihood for farmers, thus is extremely important for their everyday life. Farmers first reclaim fertile plain land, followed by the reclamation of relatively barren land in hilly and mountainous areas when plains are not enough to support the increasing population (Zeng et al., 2011; Zhang et al., 2016). However, excessive reclamation of land in mountainous areas has negatively impacted both resources and the environment, such as causing water loss and soil erosion (Han et al., 2008; Wang, 2010). In the current process of transformation from an agricultural society to an industrial, urban society in China, there are opportunities for farmers to join nonagricultural sectors. Livelihood diversification has become the main employment hallmark of farmers (Yan et al., 2009; Li et al., 2012). Because of the poor natural resources, fragile ecology, and remote location of mountainous areas in China, these are often places with a concentrated area of poverty (Liu and Li, 2017). The farmers in mountainous areas are typically subsistence farmers by relying on land resources, but cannot improve their level of wealth. To seek better sources of livelihood, a large part of the rural labor force in mountainous areas has migrated to nonagricultural sectors in cities and towns (Wang et al., 2012; Zhang et al., 2015). The human disturbance of land has been relieved with the emigration of the rural labor force out of the mountainous areas (Tian et al., 2010a), which has driven a significant land use transition and led to a series of socioeconomic and ecological effects $(\mathrm{Li}$, 2008).

The theory of land use transition introduces the concept of land use morphology and focuses on the trend of land use morphology over the long-term. This new approach has been used to comprehensively study land use and cover change (Long and Li, 2002; Long, 2012; Qu et al., 2017; Song, 2017). Suburban areas and mountainous areas are regions that face strong changes in rural land use and cover change in the process of industrialization and urbanization (Zhang, 1999; Qu et al., 2005; Zhang et al., 2005; Wu and Yang, 2008; Li and Zhao, 2011; Zhang et al., 2016). Different from the non-agriculturalization of rural land in suburban areas, the emigration of the rural labor force leads to distinct changes in rural land use, including the abandoning and marginalization of cultivated land (Hao et al., 2015; Shao et al., 2015; Lv et al., 2017), abandoned homesteads (Liu et al., 2009; Song et al., 2013), and the expansion of forestland and restoration of natural vegetation in mountainous areas (Li, 2008; Li and Zhao, 2011). Therefore, it is necessary to clarify the connotation, complexity, and trend of rural land use transition in mountainous areas of China. This research proposes policy to promote the sustainable development of mountainous areas and respond to the construction of ecological civilization, which was proposed by the Chinese government in the 18th national congress of the Communist Party of China in 2012, aiming at harmonious coexistence, virtuous circle, and all-round development.

Based on constructing a hypothesis of rural land use transition in mountainous areas, this paper systematically analyzes the laws of rural land use transition in mountainous areas in China from three aspects: the characteristics, driving forces, and effects of land use transition. Then, this paper examines the current land reclamation projects occurring in mountainous countryside and proposes improvements. In addition, the data presented in this paper 
could deepen the understanding of the theory of land use transition and provide scientific policy suggestions for the formulation of land reclamation in mountainous countryside.

\section{Scientific hypothesis of rural land use transition in mountainous areas}

Research on land use transition started in the 1990s and was first proposed by Grainger in the study of land use in forestry-dominated countries (Grainger, 1995a; 1995b). Later, other studies have applied this field of research to China (Long and Li, 2002; Long, 2012; Long, 2015). Long pointed out that land use transition is driven by socioeconomic change and innovation; it is a process when regional land use morphology changes from one form to another in a period corresponding to the transition of socioeconomic stages (Long, 2012). Land use morphology is the core research component of land use transition (Long, 2012; Qu and Long, 2017) and represents the dominant morphology of land use quantity, spatial structure attributes, and the recessive morphology of land use attributes such as quality, mode of land use management, and land use input-output (Long, 2012). The dominant and recessive morphologies of land use interact and decouple with each other to reveal the multidimensional, complex, and comprehensive characteristics of land use transition. From the perspective of socioeconomic change and land use morphological change, this paper identifies the scientific connotation of land use transition in mountainous countryside (Figure 1).

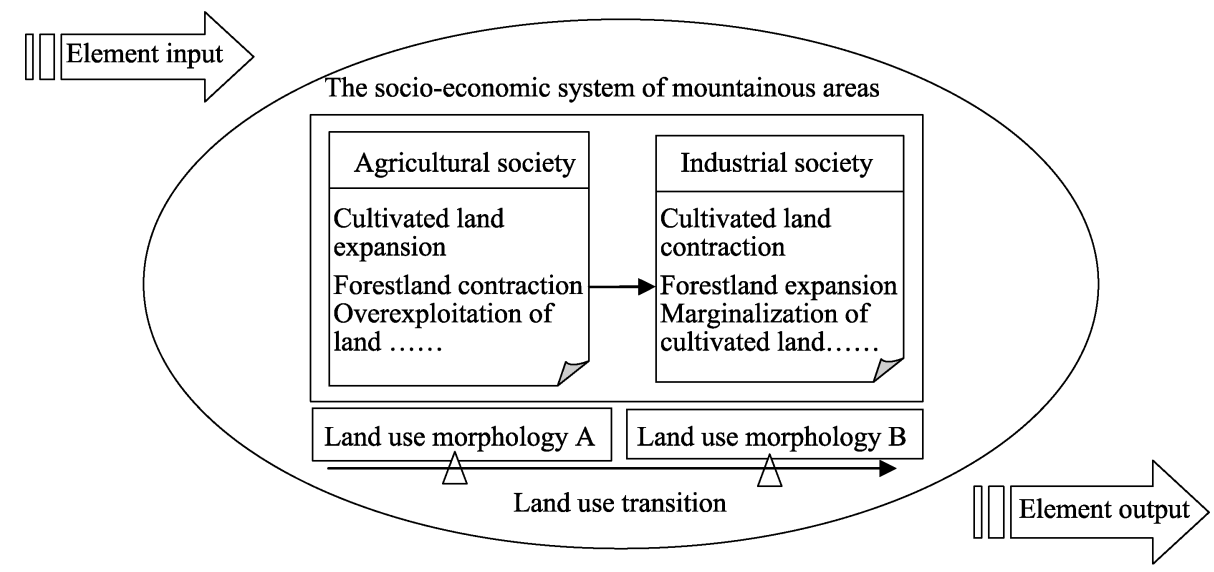

Figure 1 Theoretical framework of rural land use transition in mountainous areas

The mountainous area is an open and interconnected social ecological system with vulnerability and complexity of its characteristics. The development of agriculture in mountainous areas of China originated from the immigration and reclamation of mountainous rural land by farmers who lost their land in the plains (Han and Zhang, 2009). In the traditional agricultural era, with the passage of time and population growth, the reclamation and utilization of land by farmers followed the spatial pattern of plain, hilly and mountainous areas (Zhang et al., 2016). At the same level of input, the output of cultivated land in the mountainous area is far less than that of the plain. Expanding the area of cultivated land has become an important means for the farmers to sustain their livelihood. Therefore, the forestland in the mountainous areas was gradually reclaimed for use as cultivated land (Zeng et al., 2011). However, the natural conditions, such as climate, hydrology, soil, and topography in 
mountainous areas, are vulnerable and poor-quality, thus excessive reclamation of mountainous rural land leads to negative ecological effects such as deterioration of vegetation and soil erosion (Han et al., 2008). Therefore, the reclamation of rural land in mountainous areas and the environmental problems caused by it are the embodiment of the increasing contradiction between humans and land in an agricultural society.

Driven by rapid industrialization and urbanization, it is now not necessary to produce food in mountainous areas. The socioeconomic factors in mountainous countryside have undergone dramatic changes, such as the emigration of labor, the loss of education and medical resources, the hollowing of industry, and the depression of the economy. Driven by the external changes of industrialization, the innovation of urbanization, and the internal changes of socioeconomic factors in mountainous countryside, the artificial disturbance of rural land in mountainous areas has been alleviated, causing significant changes in land use morphology. The reclamation of cultivated land and the contraction of forestland in an agricultural society have evolved into the abandonment and marginalization of cultivated land, the expansion of forestland, and the restoration of natural vegetation. The above changes in land use morphology constitute the land use transition in mountainous countryside. Land use transition is the response of the land use system to the comprehensive role of socioeconomic development and the evolution of the ecosystem; it is in line with the general trend of socioeconomic development and ecosystem evolution. Therefore, the influence of the land use transition is decisive (Song, 2017). It is precisely because of this decision that land use policy to boost the development of the economy and the optimization of the ecosystem is based on accurately grasping the characteristics, mechanism, and effects of land use transition in mountainous countryside.

\section{Characteristics of rural land use transition in mountainous areas}

Land use transition is the change of land use morphology (Grainger, 1995b; Long and Li, 2002). Through the analysis of the turning point trends of the dominant and recessive land use morphology in mountainous countryside, the exploration of the characteristic index, and measurement of the land use transition, this paper concludes the characteristics and objectives of land use transition over the process of the evolution of an agricultural society to an industrial, urban society in mountainous countryside (Table 1).

Table 1 Characteristics of land use transition in mountainous countryside

\begin{tabular}{|c|c|c|c|}
\hline $\begin{array}{l}\text { Land use } \\
\text { transition }\end{array}$ & $\begin{array}{l}\text { Characteristic } \\
\text { attribute }\end{array}$ & $\begin{array}{l}\text { Characteristic } \\
\text { index }\end{array}$ & $\begin{array}{l}\text { Connotative } \\
\text { diagnosis }\end{array}$ \\
\hline \multirow{2}{*}{$\begin{array}{l}\text { Morphological } \\
\text { transition of } \\
\text { dominant land } \\
\text { use }\end{array}$} & $\begin{array}{l}\text { Change of quanti- } \\
\text { tative structure } \\
\text { /use conversion }\end{array}$ & $\begin{array}{l}\text { The area of land and its proportion, the } \\
\text { rate of abandoned farmland, forest and } \\
\text { grass coverage }\end{array}$ & $\begin{array}{l}\text { Farmland evolved from continuous } \\
\text { reclamation to abandonment, and for- } \\
\text { estland changed from continuous con- } \\
\text { traction to restorative growth }\end{array}$ \\
\hline & $\begin{array}{l}\text { Change of spatial } \\
\text { layout }\end{array}$ & $\begin{array}{l}\text { The terrain gradient of arable land } \\
\text { abandonment, the terrain gradient } \\
\text { covered by forest and grass, landscape } \\
\text { morphological features of land use }\end{array}$ & $\begin{array}{l}\text { Farmland abandonment and natural } \\
\text { vegetation restoration occurred in poor } \\
\text { land with steep slope and thin soil }\end{array}$ \\
\hline \multirow[b]{2}{*}{$\begin{array}{l}\text { Morphological } \\
\text { transition of } \\
\text { recessive land } \\
\text { use }\end{array}$} & $\begin{array}{l}\text { Change of land use } \\
\text { intensity }\end{array}$ & $\begin{array}{l}\text { Input-output index, average actual } \\
\text { farming area, average labor input }\end{array}$ & $\begin{array}{l}\text { The land pressure index decreased, and } \\
\text { land marginalization took place }\end{array}$ \\
\hline & $\begin{array}{l}\text { Change of land } \\
\text { function }\end{array}$ & $\begin{array}{l}\text { Production capacity of biological prod- } \\
\text { ucts, proportion of productive land use, } \\
\text { supply capacity of ecological products, } \\
\text { proportion of ecological land }\end{array}$ & $\begin{array}{l}\text { The ecological function of land con- } \\
\text { verted from degradation to recovery; } \\
\text { the important production function of } \\
\text { land is relatively low }\end{array}$ \\
\hline
\end{tabular}




\subsection{Characteristics of morphological transition of dominant land use in mountainous countryside}

The abandonment of cultivated land (Mac et al., 2000; Zhang et al., 2014a; Zhang et al., 2014b; Li and Li, 2016) and homesteads (Liu et al., 2009; Song et al., 2013), as well as the sustained expansion of the forest (Yamada et al., 2007; Li and Zhao, 2011) are the most obvious changes in the dominant morphology of land use in Chinese mountainous countryside during the process of industrialization and urbanization. The abandonment of cultivated land in mountainous areas is a new change in the relationship between humans and land within the connotation of land use transition in China. Many countries and regions have shown that large areas of farmland have been abandoned in hilly and mountainous areas (Clay et al., 1998; Holden et al., 2004; Zhang et al., 2011). The survey data from the Agricultural Ministry of Japan showed that the rate of abandonment of cultivated land in mountainous areas was approximately three times higher than that in plains ( $\mathrm{Li}$ and $\mathrm{Li}, 2016$ ). Cultivated land abandonment is also widespread in mountainous areas in China, especially in the southwest and northwest mountainous areas (Table 2). According to a previous investigation, the rate

Table 2 Characteristics of land use transition in mountainous countryside of China

\begin{tabular}{|c|c|c|}
\hline $\begin{array}{l}\text { Contents of land } \\
\text { use transition }\end{array}$ & Region & Characteristics of land use transition \\
\hline \multirow{5}{*}{$\begin{array}{l}\text { Farmland } \\
\text { abandonment }\end{array}$} & \multirow[b]{2}{*}{$\begin{array}{l}\text { Mountainous } \\
\text { areas in } \\
\text { Chongqing }\end{array}$} & $\begin{array}{l}\text { In } 2011 \text {, the abandonment rate of farmland in Wulong County, Chongqing, } \\
\text { was } 12.8 \% \text {, and the abandoned proportion of villages in middle and high } \\
\text { mountain areas was } 20 \% \text { (Zhang et al., 2014). }\end{array}$ \\
\hline & & $\begin{array}{l}\text { The abandonment rate of farmland in three counties, Shizhu, Wushan, and } \\
\text { Youyang, of Chongqing in } 2011 \text { were } 14 \%, 19.9 \% \text {, and } 19.2 \% \text { respectively; } \\
\text { the average abandonment rate was } 18 \% \text {, and the abandonment rate }(20.4 \%) \text { in } \\
\text { dry land was higher than that of the paddy field abandoned }(11.5 \%) \text { (Shi and } \\
\text { Xu, 2016). }\end{array}$ \\
\hline & $\begin{array}{l}\text { Mountainous } \\
\text { areas in south- } \\
\text { ern Ningxia }\end{array}$ & $\begin{array}{l}\text { From } 2008 \text { to } 2009 \text {, the abandonment rate of farmland, especially sloping } \\
\text { fields and dry land, was } 37.5 \% \text {, while less irrigated land was abandoned (Tian } \\
\text { et al., 2010b). }\end{array}$ \\
\hline & $\begin{array}{l}\text { Mountainous } \\
\text { areas in } \\
\text { Shaanxi }\end{array}$ & $\begin{array}{l}\text { In } 2014 \text {, the abandoned land of Mizhi County in } 2014 \text { accounted for } 32.54 \% \text {, } \\
\text { which was mainly distributed in the sunny side and large slope area of the } \\
\text { mountain, and the possibility of farmland abandonment in the sunny side was } \\
\text { greater than that in the shaded hillside (Song et al., 2016). }\end{array}$ \\
\hline & Whole country & $\begin{array}{l}13.5 \% \text { and } 15 \% \text { of the agricultural land was in idle state, respectively, } \\
\text { through the investigation of } 29 \text { provinces and } 262 \text { counties and cities in the } \\
\text { country in } 2011 \text { and } 2013 \text { ( } \mathrm{Li} \text { and } \mathrm{Li}, 2016 \text { ). During } 2014-2015 \text {, the aban- } \\
\text { donment rate of farmland in mountainous counties was } 14.32 \% \text {, showing a } \\
\text { distribution pattern of "south-high and north-low" at the provincial level. The } \\
\text { abandonment rate for the Yangtze River Basin was the highest, while that for } \\
\text { the northeastern mountainous area was the lowest (Li et al., 2017). }\end{array}$ \\
\hline $\begin{array}{l}\text { Homestead idle } \\
\text { and abandoned }\end{array}$ & $\begin{array}{l}\text { Typical vil- } \\
\text { lages in China }\end{array}$ & $\begin{array}{l}\text { The average hollowing rate of the typical villages in China was } 10.15 \% \text { in } \\
2010 \text {. The hollowing rate }(12.24 \%) \text { of homestead in mountainous countryside } \\
\text { was higher than that of the plain area }(9.91 \%) \text { and hillock area }(5.86 \%) \text { (Song } \\
\text { et al., 2013). }\end{array}$ \\
\hline \multirow{3}{*}{$\begin{array}{l}\text { Forestland } \\
\text { expansive }\end{array}$} & Chongqing & $\begin{array}{l}\text { The forest coverage rate in Chongqing increased from } 23.1 \% \text { in } 2000 \text { to } \\
42.1 \% \text { in } 2012 \text {, among them, the contribution rate of barren hills and waste- } \\
\text { land to farmland area was } 40 \% \text {, and the conversion of farmland to forest was } \\
28 \% \text { (He et al., 2016). }\end{array}$ \\
\hline & $\begin{array}{l}\text { Three Gorges } \\
\text { Reservoir area }\end{array}$ & $\begin{array}{l}\text { The proportion of forest area in the Three Gorges Reservoir area increased } \\
\text { from } 54.66 \% \text { to } 55.05 \% \text { from } 1992 \text { to } 2012 \text { (Shao et al., 2014). }\end{array}$ \\
\hline & Whole country & $\begin{array}{l}\text { During 1980-1990, forestland area has changed from continuous reduction to } \\
\text { restorative growth in China, and conversion of farmland to forest and closed } \\
\text { forest played an important role ( } \mathrm{Li} \text { and Zhao, 2011). }\end{array}$ \\
\hline
\end{tabular}


of cultivated land abandoned in four villages in the mountainous area of Chongqing reached 90.71\% in 2012 (Chen et al., 2016). Sloped and dry cultivated land in mountainous areas is first abandoned (Tian et al., 2010b). Dry land abandonment in the mountainous area of Shizhu County, Chongqing, accounted for 83.99\% from 2001 to 2011 (Shao et al., 2014). Rural homestead and cultivated land are important types of land use transition in rural China (Long and Li, 2012). Currently, in mountainous countryside, because of the emigration of the labor force, many idle and abandoned homesteads are present (Yang et al., 2012; Feng and $\mathrm{Du}, 2016)$. Compared with plains and hilly areas, the hollowing rate of rural homesteads in mountainous areas is the highest (Song et al., 2013). The restoration of forestland is accompanied by the process of abandoning cultivated land and homesteads caused by the emigration of the labor force from mountainous areas. These are important characteristics of the morphological transition of dominant land use in mountainous areas (Wang et al., 2015). The ultimate form of cultivated land abandonment is that cultivated land withdraws from agricultural production. The semi-natural artificial ecosystem gradually succeeds to a natural system, and then the natural vegetation coverage restores in mountain areas (Li and Zhao, 2011). "Forest transition," follows the pathway from the restoration of degraded forestland to secondary forest, the ecological integrity of the secondary forest is further improved, the degraded original forest is restored to the original forest, and the marginalized cultivated land is converted into secondary forest (Shao et al., 2014).

At present, from the perspective of the reforestation policy caused by ecological degradation or natural vegetation recovery caused by emigration of the labor force, scholars explain that forestland areas in mountainous countryside have changed from continuous atrophy to restorative growth and there is a turning point. This reveals the trends of land use transition in mountainous areas (Mather, 1992; Mather, 2007; Li and Zhao, 2011). However, the concept of "forest transition" cannot cover the mountainous area, which is a geographical continuum. Although measurement of the change of forest area can reveal the characteristics of land use and cover change in mountainous areas, it cannot fully reflect the scientific connotation and transition trend of rural land use in mountainous areas. Behind the dominant morphological transition, such as farmland contraction and forest expansion, more complex recessive morphological transitions have occurred in mountainous areas, indicating that the land input and intensity decreased and the ecological function of the land was restored.

\subsection{Characteristics of morphological transition of recessive land use in mountainous countryside}

Morphological transition of recessive land use in mountainous countryside can be classified as cultivated land marginalization and restoration of ecological functions. Cultivated land marginalization is a rapid change of land use pattern in mountainous countryside (Zhang et al., 2014; Shao et al., 2015), and the net income of cultivated land utilization ranges from greater to less. The form of cultivated land marginalization is the decrease of labor input and degree of land use intensity (Liu and Li, 2005; Deng et al., 2016). Cultivated land with poor quality, remote location, and low productivity is most likely to be marginalized (Tian et al., $2010 \mathrm{~b}$ ). With the further development of industrialization and urbanization in China, the possibility of marginalization of sloping cultivated land in mountainous areas is becoming higher ( $\mathrm{Li}$ and $\mathrm{Zhao}, 2011$ ). In addition, the transition of land use functions is also a promi- 
nent feature of morphological transition of recessive land use in mountainous countryside (Song, 2017), indicating the weakening of the productive function of the land and the promotion of land ecological function. In an agricultural era, the demand for productivity of cultivated land is high, thus the land was continuously cultivated in mountainous areas and the land input was increased, which led to the further degradation of the fragile ecosystem of mountainous areas. With the accelerated process of industrialization and urbanization, farmers have new sources of livelihood and the demands for the productive function of cultivated land is reduced in mountainous areas, leading to the abandonment of farmland, the restoration of natural vegetation, and the recovery of the ecological function of the land.

At present, research focuses on morphological transition of dominant land use in mountainous countryside; the impact of farmland abandonment is especially studied, which relates to the key area of land resource management in China: the protection of cultivated land. The morphological transition of recessive land use in mountainous countryside is not easily recognized, but it can reflect the deep-seated problems of land use and cover change of mountainous areas; therefore, it is the future focus of the study of land use transition in mountainous countryside. More attention should be paid to the recessive morphology of land use in mountainous countryside. The morphological transition of recessive land use is the key to policy and institution innovation and improving land management. It is also the foundation for enhancing the scientific nature of the decision-making processes related to land resource management in mountainous areas.

\subsection{Characteristics and measurement of land use transition in mountainous country- side}

Land use morphological indexes and measurement are the premise for analyzing the characteristics of land use transition. Currently, the measurement of land use transition adopts the measurement of land use/cover change (Table 3) based on land use structure and other dominant morphological indicators. However, the recessive morphological indexes have not been sufficiently considered. The dominant transition of land use in mountainous areas is embodied in the gradual withdrawal of land use types, such as those impacted by human disturbance, while the recessive transition showed the marginalization of cultivated land and the restoration of its ecological functions. The morphological transition of recessive land use (functional morphology) promotes the development of the mountain ecosystem. Thus, the connotation of land use transition in mountainous countryside should be deeply understood under the guidance of the comprehensive research concept of geographical structure and function. In addition, the dominant morphological indexes of land use could be extracted from the combined features of land use types, changes of its spatial distribution, and the amount and spatial changes of land types with significant changes. The recessive morphological indexes of land use could be extracted from the perspective of reclamation intensity and sequence of mountainous rural land, and the change of the demand for land use functions by farmers. The characteristic indexes of land use transition are constructed by coupling dominant and recessive morphology, and the complex indexes are quantified. Then, systematic methods are used to measure the land use transition in mountainous countryside (Guo et al., 2015; Li et al., 2015; Liao et al., 2015), and the characteristics of land use transition are explored from multiple angles and levels. 
Table 3 Measurement and characteristic index of land use transition

\begin{tabular}{|c|c|c|}
\hline Index of land use morphology & Measurement of land use transition & Literature \\
\hline $\begin{array}{l}\text { The proportion of rural homesteads to total construction } \\
\text { land (the change of single land use type in time series) }\end{array}$ & $\begin{array}{l}\text { Rural homestead/increase of } \\
\text { construction land }\end{array}$ & Long, 2006 \\
\hline $\begin{array}{l}\text { Quantitative change of regional land use types in } \\
\text { time series }\end{array}$ & Dynamic degree of land use & Guo et al., 2016 \\
\hline Transfer of regional land use types & Land use transfer matrix & $\begin{array}{l}\text { Chen et al., 2015; Liu } \\
\text { and Long, } 2016\end{array}$ \\
\hline $\begin{array}{l}\text { Spatial changes of production land use area/living land } \\
\text { use area/ecological land use area }\end{array}$ & Gravity center model & Lv et al., 2013 \\
\hline $\begin{array}{l}\text { Transfer coupling of cultivated land and } \\
\text { rural homestead }\end{array}$ & $\begin{array}{l}\text { Correlation analysis, coupling } \\
\text { coefficient of cultivated land and } \\
\text { homestead change }\end{array}$ & Long and $\mathrm{Li}, 2012$ \\
\hline $\begin{array}{l}\text { Spatial changes of per capita cultivated land area and } \\
\text { crop yield per unit of cultivated land }\end{array}$ & $\begin{array}{l}\text { Moran's } I \text { index, Local Moran's } I \\
\text { index }\end{array}$ & Xiang et al., 2016 \\
\hline $\begin{array}{l}\text { Tertiary industrial gross output value and its change per } \\
\text { unit land area }\end{array}$ & $\begin{array}{l}\text { Tertiary industrial gross output } \\
\text { value in district under its jurisdic- } \\
\text { tion/the area of district under its } \\
\text { jurisdiction }\end{array}$ & Qu and Long, 2016 \\
\hline
\end{tabular}

\section{Driving forces of rural land use transition in mountainous areas}

Research on the driving forces of land use transition focuses on socioeconomic and natural factors (Liu and Long, 2016), but it is believed that the driving force related to socioeconomic factors is greater ( $\mathrm{Li}, 2002$; Chen et al., 2015). The intensity of land use transition in mountainous countryside depends on the intensity of human activities. In the background of rapid industrialization and urbanization, a large number of people making up the rural labor force in the mountainous areas emigrate to the urban non-agricultural economic sectors. Labor emigration reduces the artificial disturbance of rural land, alleviates the contradiction between humans and land, and is the most direct driving force for the land use transition in mountainous countryside ( $\mathrm{Li}$ et al., 2015; Li and Li, 2016) (Figure 2). On one hand, the emigration of the rural labor force in mountainous areas leads to the reduction of investment into cultivated land, which shows the process of subleasing cultivated land for low rent or even giving the cultivated land to others (Hao et al., 2015), making the cultivated land "marginalized" (Li and Zhao, 2011). On the other hand, farmers have no time to cultivate the farmland, redistributing the labor resources and leading to the abandonment of cultivated land with lower quality, higher farming costs, and large tillage radius (He et al., 2016). The area of abandoned cultivated land is positively related to the percentage of rural labor emigration (Tian et al., 2010a).

The factors that lead to the emigration of the labor force, such as the rise of opportunity cost in agriculture, the scarcity of natural resources, and the difficult living conditions, are more fundamental driving forces of the rural land use transition in the mountainous areas ( $\mathrm{Li}$ and $\mathrm{Li}, 2016$ ). At present, the opportunity cost of the rural labor force continues to increase. The growth rate of the wages of ordinary laborers is three times higher than that of grain prices (Xin et al., 2011), which has prompted vast rural labor emigration. In 2004, a national labor shortage occurred in China, and the "Lewis turning point" is coming. That is, the turning point of the growth rate of labor demand exceeding the speed of labor supply, which means that there is a rapid rise of labor costs in all sectors of the economy, especially in 


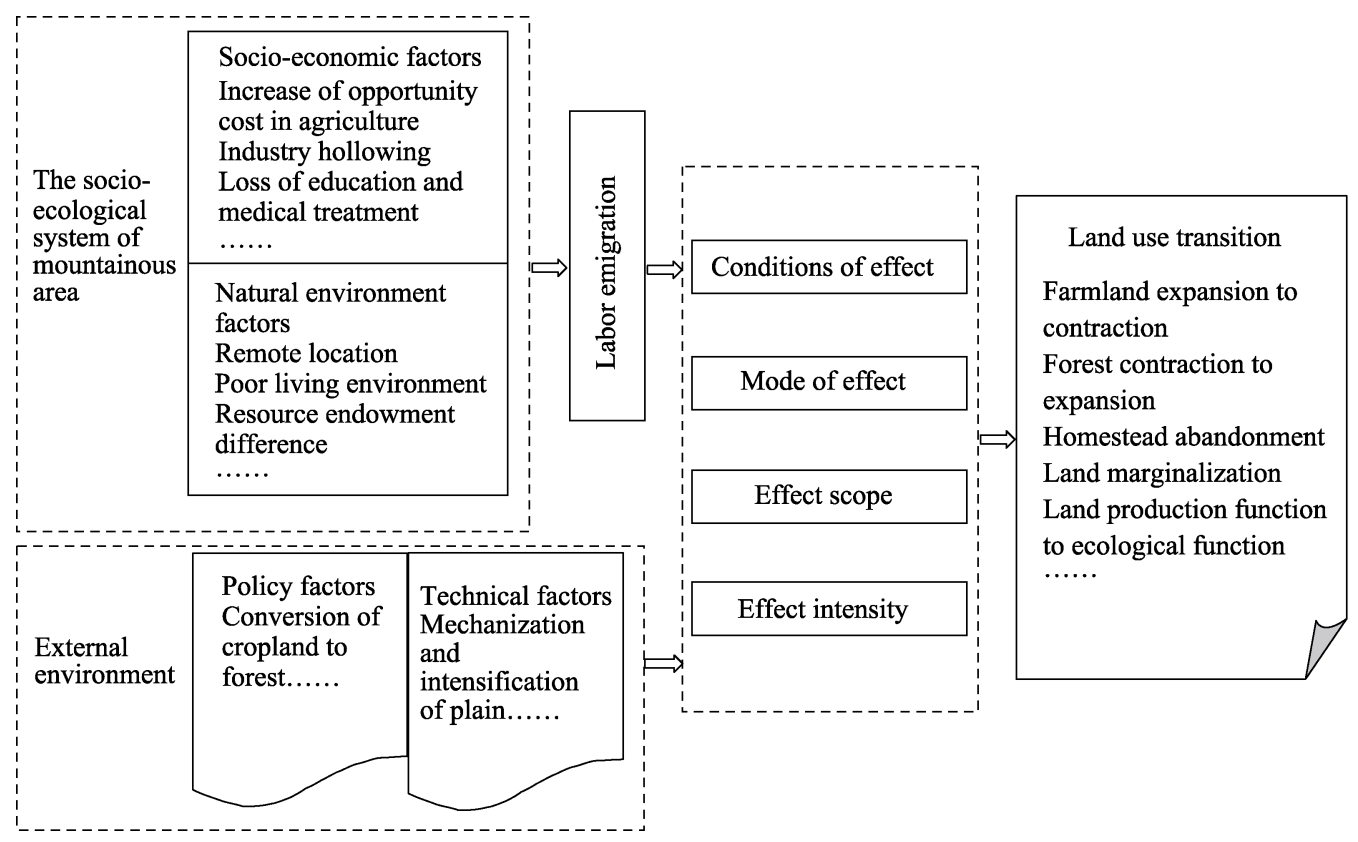

Figure 2 Mechanism of rural land use transition in mountainous areas

labor-intensive sectors ( $\mathrm{Li}$ and Zhao, 2011). In this context, the phenomena of marginalization and abandonment of cultivated land in mountainous areas will be more serious (Zhang et al., 2014). The rural land use transition in mountainous areas is also closely related to the scarcity of natural resources and the difficult living conditions in rural areas. To cope with the loss of profits caused by the decrease in the labor force or the rising cost of farming, those farming plain areas will use labor saving machinery to replace the increasingly expensive agricultural labor. However, in the mountainous areas, the labor-intensive land use pattern represented by sloping farmland is difficult to mechanize because of the natural conditions such as non-continuous farmland, steep slopes, large tillage radius, and ecological fragility. Thus, the gap of labor productivity of agriculture between mountainous and plain areas increases, also increasing the marginalization of cultivated land ( $\mathrm{Li}$ and $\mathrm{Zhao}, 2011$ ). In addition, because of the influence of the steep terrain, inconvenient transportation, lack of water source, and natural disasters in mountainous areas, farmers choose to move to areas with improved infrastructure or settle in the city, which results in the abandonment of the original rural settlement as well as nearby cultivated land (Shi and Li, 2013). In the future, the analysis of natural and socioeconomic factors promoting labor emigration away from mountainous areas should be strengthened. For example, because of the poor lifestyle and remote location, a decrease has been observed in the regional economic development of mountainous areas. Basic public service resources in rural areas have been lost due to the withdrawal of schools and the centralization of medical services, leading to the emigration of labor force and acceleration of rural land use transition of mountainous areas. In the future, the unique natural and socioeconomic factors that promote rural land use transition in the mountainous areas should be identified and quantified according to the framework of "natural, socioeconomic driving factors - labor force emigration - land use transition."

Besides the above socioeconomic and natural factors, policies have played an important 
role in the preliminary stage of rural land use transition in the mountainous areas of China (Liu and Shao, 2016), and the driving force was the "forest scarce path," the reforestation policy forced by ecological degradation ( $\mathrm{Li}$ and Zhao, 2011). Due to the fragile ecosystems in China, the policy of returning farmland to forests was implemented in the 1980s to protect and restore ecology. According to the data from the national forest resources survey, artificial afforestation contributed to a 50\% increase of forest land in the past 30 years (SFA, 2009). The promotion of agricultural technology and the intensive use of high quality cultivated land has allowed for the production of more food on less cultivated land, thus marginalizing the poor quality cultivated land. That is, the continuous improvement of intensity of high quality land in the plains crowds out farmland with poor quality in mountainous areas and provides a driving force for rural land use transition in mountainous areas (Mac et al., 2000).

\section{Effects of rural land use transition in mountainous areas}

\subsection{Ecological effects of rural land use transition in mountainous areas}

The rural land use transition in mountainous areas is conducive to environmental protection and natural recovery, prompting the adaptation of the mountain ecosystem to the regional water and temperature conditions. The morphological transition of land use in the 1980s (representing the natural environment, the forest area declines to a valley and then the elevation increases) is the most direct reason for the change of ecological conditions from its overall deterioration to its overall improvement ( $\mathrm{Li}$ and Zhao, 2011). A large number of studies have shown that the marginalization and abandonment of farmland is a reverse process of its intensive utilization and will increase the coverage of vegetation, the soil infiltration rate, and the water capacity of the soil, as well as reduce the surface water flow (Mac et al., 2000; La, 2004), reduce soil erosion, and improve the soil fertility in mountainous areas (Molinillo et al., 1997; Liu and Shao, 2016). Some studies have discussed the marginalization and abandonment of cultivated land in mountainous areas. The results show that, the abandonment of ecologically fragile farmland has prevented further damage to the mountainous ecosystem, and the pressure on the land has been alleviated (Yan et al., 2005; Li et al., 2016). This is helpful for environmental improvement (Tian et al., 2010a; Guo et al., 2015). Quantitative research has confirmed that farmland converted into forestland has made the largest contribution to the improvement of the ecological environment in the mountainous areas of southwest China (Li et al., 2016).

The ecological effects of rural land use transition in mountainous areas should focus on ecosystem security of regional land. Vulnerability and ecological security barriers are important features of land use systems in mountainous areas. Excessive human activities and land use will lead to the vulnerability of the ecosystem in mountainous areas, which is caused by the input of external material and energy in the ecosystem. The barrier function of the land ecosystem in the mountainous areas is reflected in the output of internal material and energy, and it reduces the vulnerability of the ecosystem, thus providing security for the regional ecosystem. The emigration of the rural labor force accompanies industrialization and urbanization, which has significantly changed the input and output of the material and 
energy of the ecosystem in the mountainous area, which has promoted the barrier function of the ecosystem and reduced its vulnerability. Further studies should be focused on the integration of the biodiversity index, soil conservation, water conservation, soil environment, and the effect of the carbon source - sink resulting from land use transition in mountainous areas. Also, to accurately grasp the evolution of the ecosystem security in mountainous countryside, studies should analyze the input and output changes of material and energy of the ecosystem.

\subsection{Socioeconomic effects of rural land use transition in mountainous areas}

As an important characteristic of rural land use transition in mountainous areas, the marginalization and abandonment of farmland reduces the area of crops, so in theory, it may have a negative effect on the national grain security at the macro level, the development of the mountainous countryside at the regional level, and the livelihood security of the farmers at the micro level. However, based on previous research, the significance of food security is more meaningful at the national level rather than at the regional and mountainous level (Li and $\mathrm{Li}, 2016$ ). China's large-scale project of converting farmland into forest leads to a limited reduction of grain production (Xu et al., 2006), which is estimated to be only a $2 \%-3 \%$ reduction of grain production (Feng et al., 2005). This is because of the poor quality of cultivated land in mountainous areas, its low productivity, and also the increase of land productivity of high-quality cultivated land in the plains, which will offset the reduction of grain production in mountainous areas caused by the abandonment of cultivated land (Zhao et al., 2016). This has been confirmed in Western Europe and the United States (Li, 2008).

In the aspects of the influence of land use transition on rural development in the mountainous areas, the abandonment of cultivated land and homesteads indicates the decline of the rural economy, which may negatively affect the sustainable development of the rural mountainous areas. However, if we observe this at a larger regional level, the decline of the rural economy in mountainous areas is a necessary process of socioeconomic development. Because of the increase in land productivity and the development of an economy boosted by industrialization and urbanization, the population carrying capacity in regions with fertile farmland and superior location can be greatly improved, which provides the possibility of alleviating the contradiction between humans and land in the mountainous areas. Therefore, the decline of the rural economy in mountainous areas indicates the optimization of land use pattern and the layout of socioeconomic factors at a regional level.

Considering the influence of land use transition on the livelihood security for farmers in the mountainous countryside, previous studies have focused on the impact of the reduction of agricultural income after cultivated land abandonment and marginalization ( $\mathrm{Li}$ and $\mathrm{Li}$, 2016). The paper considers that the gains from non-agricultural income caused by non-agricultural employment of emigrants may make up for the loss of agricultural income. As "rational economic man," labor emigration is the spontaneous pursuit of farmers, which has increased their income and the ability of sustainable livelihoods (Shi and Yang, 2011). However, the advantages and disadvantages of the socioeconomic effects need to be supported by empirical and quantitative research (Lambin and Meyfroidt, 2010). Socioeconomic effects should be integrated with ecological effects to explore the objectives of land 
use transition in mountainous countryside, with the focus on the promotion of an ecological civilization and to accurately manage rural development in mountainous areas.

\section{Enlightenment of land reclamation projects in mountainous countryside}

The research of land use transition can provide theoretical guidance for land consolidation, and land consolidation can boost the process of land use transition (Long and Li, 2006). At present, land resource management departments have carried out land consolidation projects including the exploitation of cultivated land reserve and the consolidation of rural residential land, with the main purpose to increase the area of cultivated land. On the one hand, there is hardly any cultivated land reserve in plain areas, thus cultivated land reserves in the mountainous areas have to be exploited (Zhang, 2003; Zhou et al., 2014). On the other hand, the compensation cost is too high for rural residential land converted into cultivated land in suburban areas. Rural residential land consolidation in the mountainous areas is a main land consolidation project to increase cultivated land (Zhang, 2016).

Nevertheless, due to the low qualify of the land resources and the fragile ecological environment in the mountainous countryside, whether the exploitation of reserve cultivated land resources or the consolidation of rural residential land, the quality and utilization of the cultivated land cannot compare with suburban and the plain areas (Zhu et al., 2013). Besides, due to the difficulty of mechanized farming because of the steep terrain of the mountainous countryside, even a small block of land is difficult to cultivate. Therefore, the cultivated land cannot be managed on a large scale and is economically marginalized and abandoned. Therefore, no matter whether the exploitation of cultivated land reserve or the consolidation of rural residential land, new cultivated land is rarely cultivated and finally will be abandoned. Taking Japan for example, after the completion of industrialization and urbanization in the 1970s, the government launched plans to revitalize and rejuvenate mountainous countryside. The government took measures, such as cultivated land consolidation and rural infrastructure improvement, in order to recover the rural economy in mountainous areas (Chen, 2003; Shi, 2008). However, there are few mountainous villages with population reflux and economic recovery; the decrease of rural population and the abandonment of farmland are still the main trends of socioeconomic development in rural Japan (Rao, 2007; Keiji, 2012).

The emigration of the labor force, the abandonment and marginalization of cultivated land, and the restoration of natural vegetation in mountainous countryside are benign processes of natural ecological optimization in the process of industrialization and urbanization, and are the objectives of socioeconomic development. Under these conditions, if the land consolidation projects in the mountainous countryside focus on the target of new farmland exploitation and cultivation of land that has fragile ecology, ecological destruction is likely to occur (Zhang et al., 2012). In addition, this is contrary to the ecological civilization strategy established by the Chinese government. Mountainous areas (including hilly areas) account for approximately $70 \%$ of the total area of China, and approximately $45 \%$ of the population in China live in these areas. The improvement of the socioeconomic well-being of these people is deeply related to the construction of a moderately prosperous society. Land consolidation projects and other engineering measures will contribute to the improvement of the well-being of farmers and the optimization of the ecology in mountains areas (Figure 3). Therefore, the land consolidation in mountainous countryside should abandon the goal of 
exploiting cultivated land reserve resources, conform to the objective laws of land use transition in mountainous countryside, and turn to the goal of environmental protection and the promotion of farmers' well-being (Chen, 2007; Sun et al., 2012). Specifically, the nature of land use and the threshold of land exploitative intensity should be clarified. In addition, the ecological security should be further considered related to land consolidation in mountainous areas (Yu et al., 2009) to avoid further damage to the ecology and to improve ecological function. Secondly, the changes of the service value of the ecosystem in mountainous countryside before and after land consolidation should be measured, and the improvement of ecosystem services should be considered an important standard for evaluating the land consolidation project. The compensation of the ecosystem services should be taken as an important means to improve farmers' well-being. Finally, the synergies of socioeconomic welfare and ecology improvement will be realized simultaneously in mountainous areas.

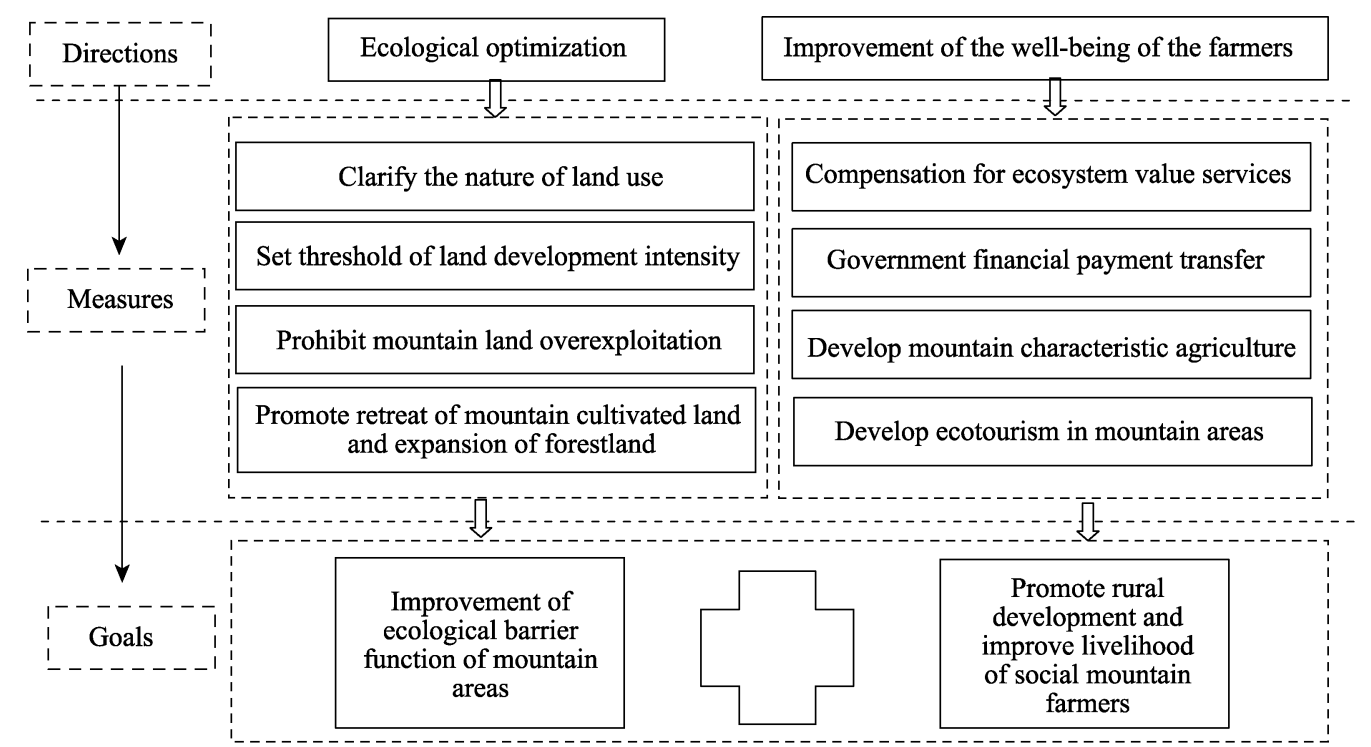

Figure 3 Target of rural land consolidation in mountainous areas

\section{Discussion and conclusions}

In the process of the transfer of an agricultural society to industrialization and urbanization, the turning point trend of land use morphology was the core of rural land use transition in mountainous areas. The morphological transition of dominant land use in mountainous countryside has changed from the expansion of farmland and the contraction of forestland to the abandonment of farmland and the restoration of forest in the process of urbanization. The marginalization of farmland and the restoration of ecological services are the morphological transition of recessive land use in mountainous countryside. In the future, a characterization index should be constructed relating to land use change in mountainous areas by coupling dominant and recessive land use morphologies and testing a variety of methods to measure the land use transition. In addition, the characteristics and objective laws of land use transition in mountainous countryside should be studied from multiple angles and levels. 
The rural land use transition in mountainous areas is driven by the external environment of industrialization, urbanization, and the change of the mountainous socio-ecological system. Socioeconomic factors are the primary driving forces during land use transition in mountainous areas, with labor emigration mitigating the contradiction between humans and land being the most direct force. The rising costs of farming and the harsh living environment leading to labor emigration were the fundamental driving forces. In the future, the identification and quantification of the unique natural and socioeconomic factors that propel the labor emigration out of mountainous countryside should be studied, following the framework of "natural, socioeconomic driving factors - emigration of labor force - land use transition."

The rural land use transition in mountainous areas promotes the ecological environment to the pattern adapted to the regional hydrothermal conditions, reduces the vulnerability of the land ecosystem, and improves the ecological function of the land. Socioeconomic effects of rural land use transition in mountainous areas should be studied from the regional socio-ecological system level to explore the impact on the rural development of mountainous areas and the sustainable livelihood of farmers. The advantages and disadvantages of socioeconomic effects need to be supported by empirical and quantitative research.

The rural land use transition in mountainous areas is a process of natural recovery and ecological optimization and also the inevitable objective of socioeconomic development. The land consolidation project in mountainous countryside should comply with the objective laws of land use transition, "ecological priority" strategy should be carried out, and the target orientation will shift from increasing the area of farmland to the synergies of economic welfare increases for farmers and ecological optimization of mountainous areas.

In the current research on land use change in mountainous areas of China, some scholars have studied the spatial and temporal pattern of land exploitation in the agricultural society (Han et al., 2008; Wang, 2010; Zeng et al., 2011); however, more scholars have focused on cultivated land abandonment due to the rapid development of industrialization and urbanization (Tian et al., 2010b; Li and Zhao, 2011; Zhang et al., 2014a; Li and Li, 2016; Li et al., 2017). Few studies have been conducted on land use change in an agricultural society to the present based on a long-term perspective. With the theory of land use transition, this paper discussed the change of rural land use morphology in mountainous areas over the long-term, which enriched the current research content on mountainous land use transition. Under the background of carrying out the strategy of rural revitalization in China, the research on rural land use transition in mountainous areas has more direct policy and practical value.

Future studies cannot only focus on argumentative or deductive research on the current land policy, but also must analyze the morphology and characteristics of rural land use in mountainous areas of China according to the objectives of the ecosystem and the socioeconomic system. Moreover, this paper clarifies the driving mechanism and effect of the land use transition, analyzes the laws of rural land use transition in mountainous areas, and takes it as the basis for evaluating and improving the current rural land policies in mountainous areas. In addition, this paper discusses mountainous countryside areas with remote locations and decreasing economic development. Although the characteristics of land use transition in urban mountainous areas are the expansion of forestland and the restoration of vegetation, the driving force is not labor emigration but increasing demand for leisure tourism of urban 
residents that drives the changes in the land use decisions by farmers. In the future, a comparative study on driving forces of rural land use transition in urban mountainous areas and remote mountainous areas should be strengthened.

\section{References}

Chen G J, 2007. Some considerations on strategy of development of mountain regions of China. Bulletin of Chinese Academy of Sciences, 22(2): 126-131. (in Chinese)

Chen L, Zhou S L, Zhou B B et al., 2015. Characteristics and driving forces of regional land use transition based on the leading function classification: A case study of Jiangsu Province. Economic Geography, 35(2): $155-162$. (in Chinese)

Chen X P, Xin G X, Wei C F, 2016. An analysis of farmland abandonment in poor mountainous areas and its influencing factors: A case study of four villages in two townships of Youyang County, Chongqing. Journal of Southwest University (Natural Science Edition), 38(9): 166-174. (in Chinese)

Chen Y N, 2003. Enlightenment to China by studying agriculture economic development of Japanese mountain area: A review of country problems in Japan. China Soft Science, (8): 106-109. (in Chinese)

Clay D C, Reardon T, Kangasniemi J, 1998. Sustainable intensification in the highland tropics: Rwandan farmers' investments in land conservation and soil fertility. Economic Development and Cultural Change, 46(2): 351-378.

Deng H, Shao J A, Wang J L et al., 2016. Land use driving forces and its future scenario simulation in the Three Gorges Reservoir Area using CLUE-S model. Acta Geographica Sinica, 71(11): 1979-1997. (in Chinese)

Feng J, Du Y, 2016. The aspiration of renovation of hollow villages: An investigation of Xiji County, Ningxia Hui Autonomous Region. Human Geography, (6): 39-48. (in Chinese)

Feng Z M, Yang Y Z, Zhang Y Q et al., 2005. Grain-for-Green policy and its impacts on grain supply in West China. Land Use Policy, 22(4): 301-312.

Grainger A, 1995a. The forest transition: An alternative approach. Area, 27(3): 242-251.

Grainger A, 1995b. National land use morphology: Patterns and possibilities. Geography, 80(3): $235-245$.

Guo C Y, Gao J H, Fan P F et al., 2016. Land use transition and hotspots detection in Yongcheng City based on the grid scale. China Land Sciences, 30(4): 43-51. (in Chinese)

Guo L Y, Di L P, Li G et al., 2015. GIS-based detection of land use transformation in the Loess Plateau: A case study in Baota District, Shaanxi Province, China. Journal of Geographical Sciences, 25(12): 1467-1478.

Han M L, Zhang W W, 2009. Spatial and temporal variation of settlements of Bairin Left Banner in Xiliao River Valley in the first half of 20th century. Scientia Geographica Sinica, 29(1): 71-77. (in Chinese)

Han M L, Zhang Y, Fang C et al., 2008. Location and environment of the settlements and man-land relationship in West Liaohe River Basin since Holocene. Geographical Research, 27(5): 1118-1128. (in Chinese)

Hao H G, Li X B, Zhang H Y et al., 2015. Impact of the opportunity cost of farming labor on the agricultural land marginalization. Journal of Arid Land Resources and Environment, 29(3): 50-56. (in Chinese)

He W F, Yan J Z, Zhou H et al., 2016. The micro-mechanism of forest transition: A case study in the mountainous areas of Chongqing. Journal of Natural Resources, 31(1): 102-113. (in Chinese)

Holden S, Shiferaw B, Pender J, 2004. No-farm income, household welfare, and sustainable land management in a less-favoured area in the Ethiopian highlands. Food Policy, 29(4): 369-392.

Keiji U, 2012. Present situation and crisis of Japan's agriculture and rural areas. Agricultural History of China, (1): 73-87.

La B, 2004. Hydrological functions of tropical forests: Not seeing the soil for the trees? Agriculture, Ecosystems \&Environment, 104(1): 185-228.

Lambin E F, Meyfroidt P, 2010. Land use transitions: Socio-ecological feedback versus socio-economic change. Land Use Policy, 27(2): 108-118.

Li C K, Xin G X, Yang C X et al., 2016. Land use and land cover change (LUCC) and its environmental effects of traditional farm area. Journal of Southwest University (Natural Science Edition), 38(5): 139-145. (in Chinese)

Li C Z, Xu J C, Kong X B, 2012. Farm household livelihood diversity and land use in suburban areas of the me- 
tropolis: The case study of Daxing district, Beijing. Geographical Research, 31(6): 1039-1049. (in Chinese)

Li S F, Li X B, 2016. Progress and prospect on farmland abandonment. Acta Geographica Sinica, 71(3): 370-389. (in Chinese)

Li S J, Li X B, Tan M H, 2015. Impacts of rural-urban migration on vegetation cover in ecologically fragile areas: Taking Inner Mongolia as a case. Acta Geographica Sinica, 70(10): 1622-1631. (in Chinese)

Li T T, Long H L, Liu Y Q et al., 2015. Multi-scale analysis of rural housing land transition under China's rapid urbanization: The case of Bohai Rim. Habitat International, 48(8): 227-238.

Li X B, 2002. Explanation of land use changes. Progress in Geography, 21(3): 195-203. (in Chinese)

Li X B, 2008. Theoretical hypotheses about agricultural land use changes and the relevant propositions about environmental impacts. Advances in Earth Science, 23(11): 1124-1129. (in Chinese)

Li X B, Zhao Y L, 2011. Forest transition, agricultural land marginalization and ecological restoration. China Population, Resources and Environment, 21(10): 91-95. (in Chinese)

Liao L W, Qin J X, Liu Y Q et al., 2015. Study on ecological elasticity of Hunan Province based on land use transition. Economic Geography, 35(9): 16-23. (in Chinese)

Liu C W, Li X B, 2005. The character and diagnostic criterion for marginiastion of the arable land. Progress in Geography, 24(2): 106-113. (in Chinese)

Liu T, Shao J A, 2016. Spatial and temporal variation of soil erosion under different land uses in the Three Gorges Reservoir Region. Science of Soil and Water Conservation, 14(3): 1-9. (in Chinese)

Liu Y Q, Long H L, 2016. Land use transitions and their dynamic mechanism in the Huang-Huai-Hai Plain. Acta Geographica Sinica, 71(4): 666-679. (in Chinese)

Liu Y S, Li J T, 2017. Geographic detection and optimizing decision of the differentiation mechanism of rural poverty in China. Acta Geographica Sinica, 72(1): 161-173. (in Chinese)

Liu Y S, Liu Y, Zhai R X, 2009. Geographical research and optimizing practice of rural hollowing in China. Acta Geographica Sinica, 64(10): 1193-1202. (in Chinese)

Long H L, 2006. Rural housing land transition in China: Theory and verification. Acta Geographica Sinica, 61(10): 1093-1100. (in Chinese)

Long H L, 2012. Land use transition and rural transformation development. Progress in Geography, 31(2): 131-138. (in Chinese)

Long H L, 2015. Land use transition and land management. Geographical Research, 34(9): 1607-1618. (in Chinese)

Long H L, Li T T, 2012. Analysis of the coupling of farmland and rural housing land transition in China. Acta Geographica Sinica, 67(2): 201-210. (in Chinese)

Long H L, Li X B, 2002. Analysis of regional land use transition: A case study in Transect of the Yangtze River. Journal of Natural Resources, 17(2): 144-149. (in Chinese)

Long H L, Li X B, 2006. Cultivated-land transition and land consolidation and reclamation in China: Research progress and frame. Progress in Geography, 25(5): 67-76. (in Chinese)

Lv L G, Zhou S L, Zhou B B et al., 2013. Land use transformation and its eco-environmental response in process of the regional development: A case study of Jiangsu Province. Scientia Geographica Sinica, 33(12): 1442-1449. (in Chinese)

Lv X, Zang T, Zhang Q J, 2017. Farm households' cognition of land policy and its effect on farmland transfer: Based on the investigation of 287 farmer households in Shandong province. Journal of Nanjing Agricultural University (Social Science), 17(5): 100-110. (in Chinese)

Mac D D, Crabtree J R, Wiesinger G, 2000. Agricultural abandonment in mountain areas of Europe: Environmental consequences and policy response. Journal of Environmental Management, 59(1): 47-69.

Mather A S, 1992. The forest transition. Area, 24(4): 367-379.

Mather A S, 2007. Recent Asian forest transitions in relation to forest-transition theory. International Forestry Review, 9(1): 491-502.

Molinillo M, Lasanta T, García-Ruiz R J, 1997. Managing mountainous degraded landscapes after farmland abandonment in the Central Spanish Pyrenees. Environmental Management, 21(4): 587-598.

Qu F T, Chen J L, Chen W, 2005. Theoretical and empirical study on the land conversion economic driving forces. Journal of Natural Resources, 20(2): 231-241. (in Chinese) 
Qu Y, Long H L, 2016. Spatial differentiation of the recessive morphology of urban land use and its influential factors: A case study of 289 prefecture-level cities in China. Economic Geography, 36(10): 1-8. (in Chinese)

Qu Y, Long H L, 2017. The integrated research on regional land use recessive morphology from the perspectives of exploitation and output: The case of the Huang-Huai-Hai Region. Geographical Research, 36(1): 61-73. (in Chinese)

Qu Y B, Jiang G H, Zhang B L et al., 2017. Spatial characteristics of rural residential land transition and its economic gradient differentiation. Acta Geographica Sinica, 72(10): 1845-1858. (in Chinese)

Rao C K, 2007. Mechanism and political measures of Japanese rural depopulation and its reference to the Chinese rural construction. Journal of Zhejiang University (Humanities and Social Sciences), 37(6): 147-156. (in Chinese)

Shao J A, Guo Y, Chen Y et al., 2014. Characteristics of forest landscape degradation in the Three Gorges Reservoir Area (Chongqing) in the past 20 years. Journal of Southwest University (Natural Science Edition), 36(11): 1-11. (in Chinese)

Shao J A, Zhang S C, Li X B, 2014. Farmland marginalization in the mountainous areas: Characteristics, influencing factors and policy implications. Acta Geographica Sinica, 69(2): 227-242. (in Chinese)

Shao J A, Zhang S C, Li X B, 2015. Farmland marginalization in the mountainous areas: Characteristics, influencing factors and policy implications. Journal of Geographical Sciences, 25(6): 701-722.

Shi T C, Li X B, 2013. Farmland abandonment in Europe and its enlightenment to China. Geography and Geo-Information Science, 29(3): 101-103. (in Chinese)

Shi T C, Xu X H, 2016. Extraction and validation of abandoned farmland parcel in typical counties of Chongqing. Transactions of the Chinese Society of Agricultural Engineering, 32(24): 261-267. (in Chinese)

Shi Y L, 2008. The causes of Japanese rural depopulation and its influence on agricultural development. Agricultural Economy, (8): 39-40. (in Chinese)

Shi Z L, Yang Y Y, 2011. Migrant workers of rural labor ability development influence and policy implication. Management World, (12): 40-54. (in Chinese)

Song S X, Liang X Y, Mei Y J et al., 2016. Modeling and simulating land abandonment behavior of farmer households based on the CBDI. Journal of Natural Resources, 31(11): 1926-1937. (in Chinese)

Song W, Chen B M, Zhang Y, 2013. Typical survey and analysis on influencing factors of village-hollowing of rural housing land in China. Geographical Research, 32(1): 20-28. (in Chinese)

Song X Q, 2017. Discussion on land use transition research framework. Acta Geographica Sinica, 72(3): $471-487$. (in Chinese)

State Forestry Administration, P.R.C (SFA), 2009. China Forest Resources Report: Seventh National Forest Resource Inventory. Beijing: China Forestry Publishing House. (in Chinese)

Sun H L, Zheng D, Yao T D et al., 2012. Protection and construction of the national ecological security shelter zone on Tibetan Plateau. Acta Geographica Sinica, 67(1): 3-12. (in Chinese)

Tian Y J, Li X B, Ma G X et al., 2010a. Influences of labor emigration from agriculture on the production abandonment of cultivated land in ecological sensitive areas. China Land Science, 24(7): 4-9. (in Chinese)

Tian Y J, Li X B, Ma G X, 2010b. Impacts of household labor and land endowment on rural-to-urban labor migration: A case study on mountainous areas of southern Ningxia. Resources Science, 32(11): 2160-2164. (in Chinese)

Wang H, 2010. The land reclamation and its influence on ecological environment in Suide-zhou during Qing dynasty. Agricultural History of China, (2): 22-31. (in Chinese)

Wang J L, Shao J A, Li Y B, 2015. Geo-spectrum based analysis of crop and forestland use change in the recent 20 years in the Three Gorges Reservoir Area. Journal of Natural Resources, 30(2): 235-247. (in Chinese)

Wang L P, Wang C, Li X Q, 2012. Research on rural household differentiation based on the quantification of livelihood assets: Evidence from 471 rural households in Bailin village, Shapingba district, Chongqing city. Geographical Research, 31(5): 945-954. (in Chinese)

Wu C F, Yang Z R, 2008. Comparatively study on land conversion driving factor: Theory and empirical analysis. Journal of Zhejiang University (Humanities and Social Sciences), 38(2): 29-37. (in Chinese)

Xiang J W, Li J F, Zeng J, 2016. Spatial difference and its influence factors of cultivated land transition of poverty counties in west of Hubei. Transactions of the Chinese Society of Agricultural Engineering, 32(1): 272-279. 
(in Chinese)

Xin L J, Li X B, Tan M H et al., 2011. The rise of ordinary labor wage and its effect on agricultural land use in present China. Geographical Research, 30(8): 1391-1400. (in Chinese)

Xu Z G, Xu J T, Deng X Z et al., 2006. Grain for green versus grain: Conflict between food security and conservation set-aside in China. World Development, 34(1): 130-148.

Yamada S, Okubo S, Kitagawa Y, 2007. Restoration of weed communities in abandoned rice paddy fields in the Tama Hills, central Japan. Agriculture, Ecosystems \& Environment, 119(2): 88-102.

Yan J Z, Wu Y Y, Zhang Y L et al., 2009. Livelihood diversification of peasants and nomads of eastern transect in Tibetan Plateau. Acta Geographica Sinica, 64(2): 221-233. (in Chinese)

Yan J Z, Zhang Y L, Bai W Q et al., 2005. Livelihood succession and land use/cover change in the Upper Reaches of Dadu River watershed. Transactions of the Chinese Society of Agricultural Engineering, 21(3): 83-89. (in Chinese)

Yang R, Liu Y S, Chen Y F, 2012. Comprehensive measure and partition of rural hollowing in China. Geographical Research, 31(9): 1697-1706. (in Chinese)

Yu K J, Yuan H, Li D H et al., 2009. Difficulties and solutions of the sustainable land use strategy in suburban hilly area in Beijing. China Land Science, 23(11): 3-8. (in Chinese)

Zeng Z Z, Fang X Q, Ye Y, 2011. The process of land cultivation based on settlement names in Jilin Province in the past 300 years. Acta Geographica Sinica, 66(7): 985-993. (in Chinese)

Zhang A L, 1999. The mechanism agricultural land transfer and the institutional innovation of urban-rural eco-economic fringe area. Chinese Rural Economy, (7): 43-49. (in Chinese)

Zhang B L, Cai W M, Zhang F R et al., 2016. Spatio-temporal evolution of rural settlements and its driving forces in Yishui County, Shandong Province from Sui Dynasty to 1949. Geographical Research, 35(6): 1141-1150. (in Chinese)

Zhang B L, Yang Q Y, Yan Y et al., 2011. Characteristics and reasons of different households' farming abandonment behavior in the process of rapid urbanization: Based on a survey from 540 households in 10 counties of Chongqing municipality. Resources Science, 33(11): 2047-2054. (in Chinese)

Zhang B L, Zhang F R, Qu B D et al., 2015. Rural non-agricultural differences and their driving forces at the county level: A case study of 16 villages in Yishui, Shandong, East China. Acta Geographica Sinica, 70(6): 1008-1021. (in Chinese)

Zhang F R, 2003. It is more important to keep the production capacity of arable land: Understanding of the total arable land dynamic balance under the new situation. China Land, (7): 13-15. (in Chinese)

Zhang F R, An P L, Kong X B et al., 2005. Use and protection of cultivated land and prime farmland in comprehensive land use planning of Beijing. China Land Science, 19(1): 10-16. (in Chinese)

Zhang Y, Li X B, Song W, 2014a. Determinants of cropland abandonment at the parcel, household and village levels in mountain areas of China: A multi-level analysis. Land Use Policy, 41(11): 186-192.

Zhang Y, Li X B, Song W et al., 2014b. Effect of agricultural laborer on cropland abandonment under land circulation at different levels in Wulong County, Chongqing City. Progress in Geography, 33(4): 552-560. (in Chinese)

Zhang Z F, Wang Q, Gu X K, 2012. Ecosystem-services value response of land comprehensive consolidation in Xiushan Autonomous County. China Land Science, 26(7): 50-55. (in Chinese)

Zhao Y L, Zhang M, Li X B et al., 2016. Farmland marginalization and policy implications in mountainous areas: A case study of Renhuai City, Guizhou. Journal of Resources and Ecology, 7(1): 61-67.

Zhou J, Zhang F R, Wang X L et al., 2014. Spatial-temporal change and analysis of land consolidation's newly increased cultivated land in China. Transactions of the Chinese Society of Agricultural Engineering, 30(19): 282-289. (in Chinese)

Zhu T F, Zhang F R, Li C et al., 2013. Estimation and validation of rural residential land consolidation potential based on vegetation coverage rate. Transactions of the Chinese Society of Agricultural Engineering, 29(1): 240-249. (in Chinese) 